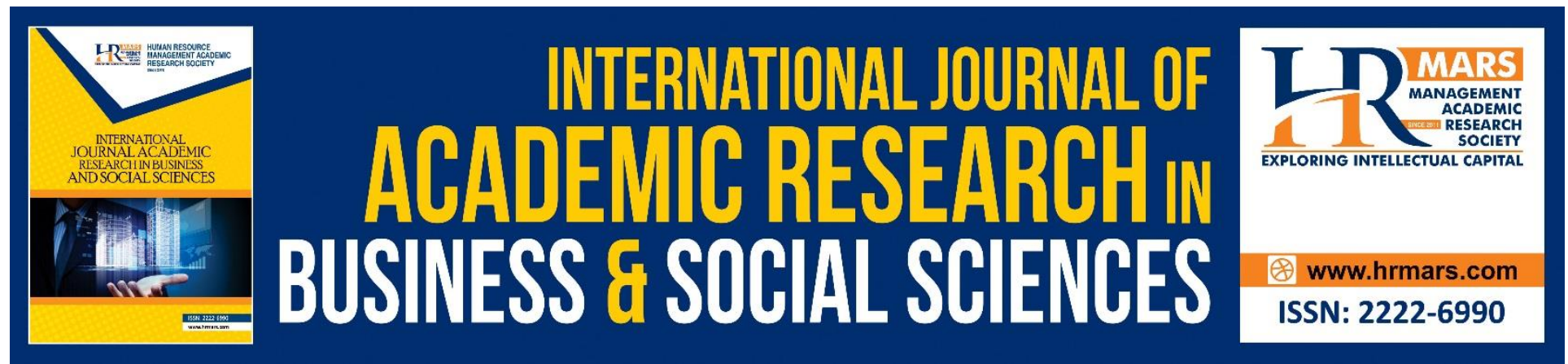

\title{
Exploring Factors Impacting on Psychological Well-Being of Health Care Workers
}

Farah Shazlin Johari

Rosmini Omar

To Link this Article: http://dx.doi.org/10.6007/IJARBSS/v9-i2/5711

DOI: $\quad 10.6007 /$ IJARBSS/v9-i2/5711

Received: 12 Jan 2019, Revised: 03 Feb 2019, Accepted: 25 Feb 2019

Published Online: 03 March 2019

In-Text Citation: (Johari \& Omar, 2019)

To Cite this Article: Johari, F. S., \& Omar, R. (2019). Exploring Factors Impacting on Psychological Well-Being of Health Care Workers. International Journal of Academic Research in Business and Social Sciences, 9(2), 5672-5684.

Copyright: (C) 2019 The Author(s)

Published by Human Resource Management Academic Research Society (www.hrmars.com)

This article is published under the Creative Commons Attribution (CC BY 4.0) license. Anyone may reproduce, distribute, translate and create derivative works of this article (for both commercial and non-commercial purposes), subject to full attribution to the original publication and authors. The full terms of this license may be seen

at: http://creativecommons.org/licences/by/4.0/legalcode

Vol. 9, No. 2, 2019, Pg. 1210 - 1222

http://hrmars.com/index.php/pages/detail/IJARBSS

JOURNAL HOMEPAGE

Full Terms \& Conditions of access and use can be found at http://hrmars.com/index.php/pages/detail/publication-ethics 


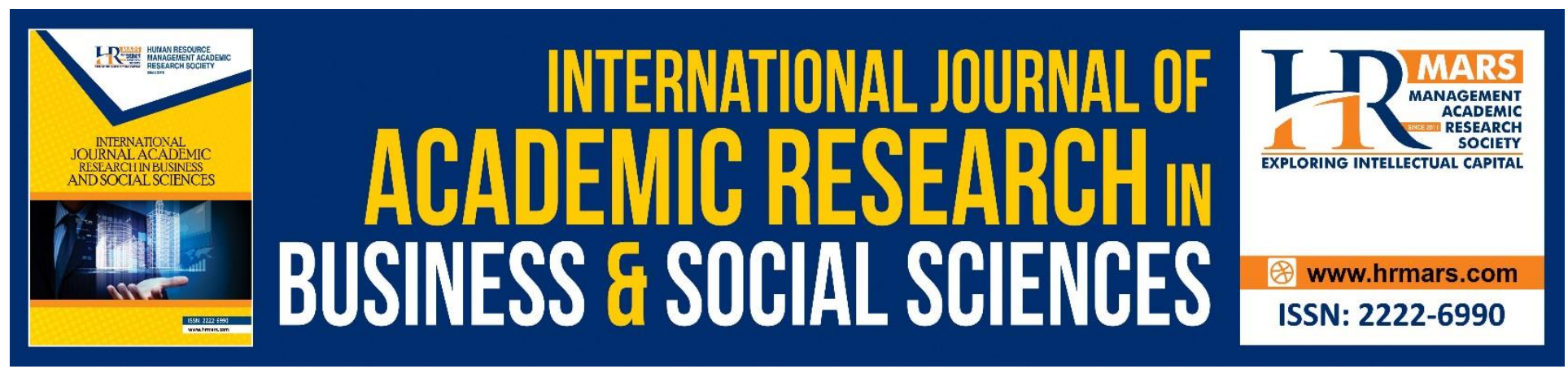

\title{
Exploring Factors Impacting on Psychological Well-Being of Health Care Workers
}

\author{
Farah Shazlin Johari \\ Universiti Teknologi MARA, Universiti Teknologi Malaysia, Malaysia \\ Rosmini Omar \\ Universiti Teknologi Malaysia. Malaysia
}

\begin{abstract}
Well-being is becoming an important consideration in developing sustainable competitive edge for better worker performance and fulfilment. While the previous studies on well-being have mainly explored workers in different industries, factors impacting on psychological well-being of health care workers have yet to be fully determined. This study aims to explore the trendsetting within the context of psychological well-being. Owing to the nature of public and private health care providers, health care workers working in different settings are expected to demonstrate different factors relating to well-being. This scoping review aims to determine what is known about the psychological well-being of health care workers, specifically to answer the questions: What factors impacting on psychological well-being have been reported among health care workers? The purpose of this review was to classify existing literatures on the specific topic and proposed integrated view of work-related and psychosocial related factors impacting on psychological well-being of health care workers. Three databases, namely Science Direct, Emerald and Proquest were accessed to search for relevant studies.

Keywords: Psychological, Well-Being, Health Care Workers, Health Care Providers, Scoping Review

\section{Introduction}

The well-being is becoming an important consideration in developing sustainable competitive edge for better worker performance and fulfillment (Demo and Paschoal, 2013). The importance of workers' well-being lies in both its relationship to performance and because it is a crucial component of healthy organizations (Pawar, 2016). As reported in Legatum Prosperity Index in 2016, it stated the important link between psychological well-being and performance rating and the findings suggest that organizations can improve the overall effectiveness by increasing workers' well-being.
\end{abstract}


The concept of psychological well-being is comprise of both positive and negative dimension including mental health, psychological distress and psychiatric disorders (Headey, Kelley and Wearing; 1993). Accordingly, psychological well-being is defined as a state of well-being characterized by self-acceptance, environmental mastery, purpose in life, personal growth, autonomy and positive relations (Synder, Lopez and Pedrotti; 2011). Even though, worker well-being represents a critical issue in every work environment, however, its importance is significantly higher in the field of medicine, as medicine involved with decision regarding public health (De Simone, 2015). Particularly, there has been growing interest previously in the wellbeing of workers in demanding occupations such as in health care sector and emergency vocations, where workers experiencing higher risks of poor mental and physical health (Bennett et al., 2004; Ramirez et al., 1996), consequently, result in chronic and acute stressors (Payne and Firth-Cozens, 1987; Rees and Cooper, 1992).

The health and well-being of health care workers should always be scrutinized to ensure the best outcome for patients. Previous studies reported a linked in worker well-being with decreased workplace turnover (Wright and Bonett, 2007); improved physical health (Richman et al., 2005) and higher worker performance (Wright and Cropanzano, 2000). Furthermore, in case of poor well-being and moderate to high levels of burnout among health professionals are associated with poor patient safety outcomes such as medical errors, due to health professionals are either feeling ill while present at work, or feel disengaged and demotivated (Shanafelt et al., 2012). Thus, it is strongly suggested improving and enhancing overall workers' well-being significantly result in better patient experience (Maben et al., 2012).

Hence, in improving the overall well-being, it is crucial to identify significant predicting factors associated with employees' psychological well-being. As reported in previous literatures, psychological well-being is affected by several factors including motivation, job satisfaction, selfefficacy, achievement, deindividuation, physical and psychological fatigue, environment and organization identification psychological fatigue, environment, and organization identification (Mackenzie et al., 2006; Li et al, 2010; Kuo, Lin and Li, 2014; Rodwell and Munro, 2013). Even though health care workers were identified as high risk occupation, however, there has been relatively little research on the factors relating to well-being among them. In recent years, different work-related and psychosocial factors impacting on psychological well-being at work have been evaluated. Therefore, this study aims to explore the factors impacting on psychological well-being of health care workers in different settings of public and private health care providers.

\section{Method}

The protocol and methodology for JBI Scoping Reviews was developed and informed by the Joanna Briggs Institute (Peters et al., 2015). This review aims to determine what is known about the psychological well-being of health care workers in public and private health care providers, specifically in answering the question: What factors impacting on psychological wellbeing have been reported among health care workers? The purpose of the review was to identify existing literatures on the specific topic and classify work-related and psychosocial factors relating to well-being for future recommendation in the field of psychological well-being of health care workers. 


\section{Inclusion Criteria}

\section{Types of Participant}

For this review, researchers included studies that focused on health care workers working in public and private health care providers.

\section{Concept}

The core concept examined by the review was "psychological well-being" and "health care workers" with the outcomes relating to factors influencing psychological well-being.

\section{Types of Sources}

The sources for this review included qualitative and quantitative studies, original and research paper, and peer reviewed research studies.

\section{Search Strategy}

Three databases, namely Science Direct, Emerald and Proquest were accessed to search for relevant studies using the keyword of "psychological well-being" and "health care workers." The search was limited to full text papers, published in English, between the years 2008 and 2018. In addition, the search engine Google Scholar was searched for additional missed papers.

\section{Selection and Extraction}

Across the three databases, a total of 613 abstracts were obtained. Three additional records were identified through the search engine Google. Following removal of duplicates, 603 records remained. Titles "psychological well-being" was screened for relevance and leaving 44 literatures for further review. Among these literatures, only 22 were considered after screening the abstract and it significant relating to research question. A further 13 were removed after full text and application of inclusion criteria were reviewed, only a total of 9 literatures were leaving for the final review (Figure 1). Data were extracted in order to include the important criteria including: author, year, objective or purpose, sample, method and findings.

\section{Result}

According to the Table 1, across the 9 included studies, two of studies were reported in 2018 and 2013 year of publication respectively, meanwhile only one study was reported for other year of publication including 2016, 2015, 2014, 2009 and 2008. The objective or purpose for the study mainly to examine the predicting factors associating with health care workers' well-being. The majority of sample in these nine studies were focusing on nurses including registered community nurses, experienced nurses, staff nurse and midwives, followed by doctor, physician and other health care workers. The research methodology for these nine studies would be different, however, a cross-sectional design study were mainly use as a research method. The following table 1 presents the findings of the literature review, including author(s), year of publication, purpose or objective, sample of the study, method of analysis used and findings of factors relating to psychological well-being of the study. 
INTERNATIONAL JOURNAL OF ACADEMIC RESEARCH IN BUSINESS AND SOCIAL SCIENCES Vol. 9, No. 2, Feb, 2019, E-ISSN: 2222-6990 @ 2019 HRMARS

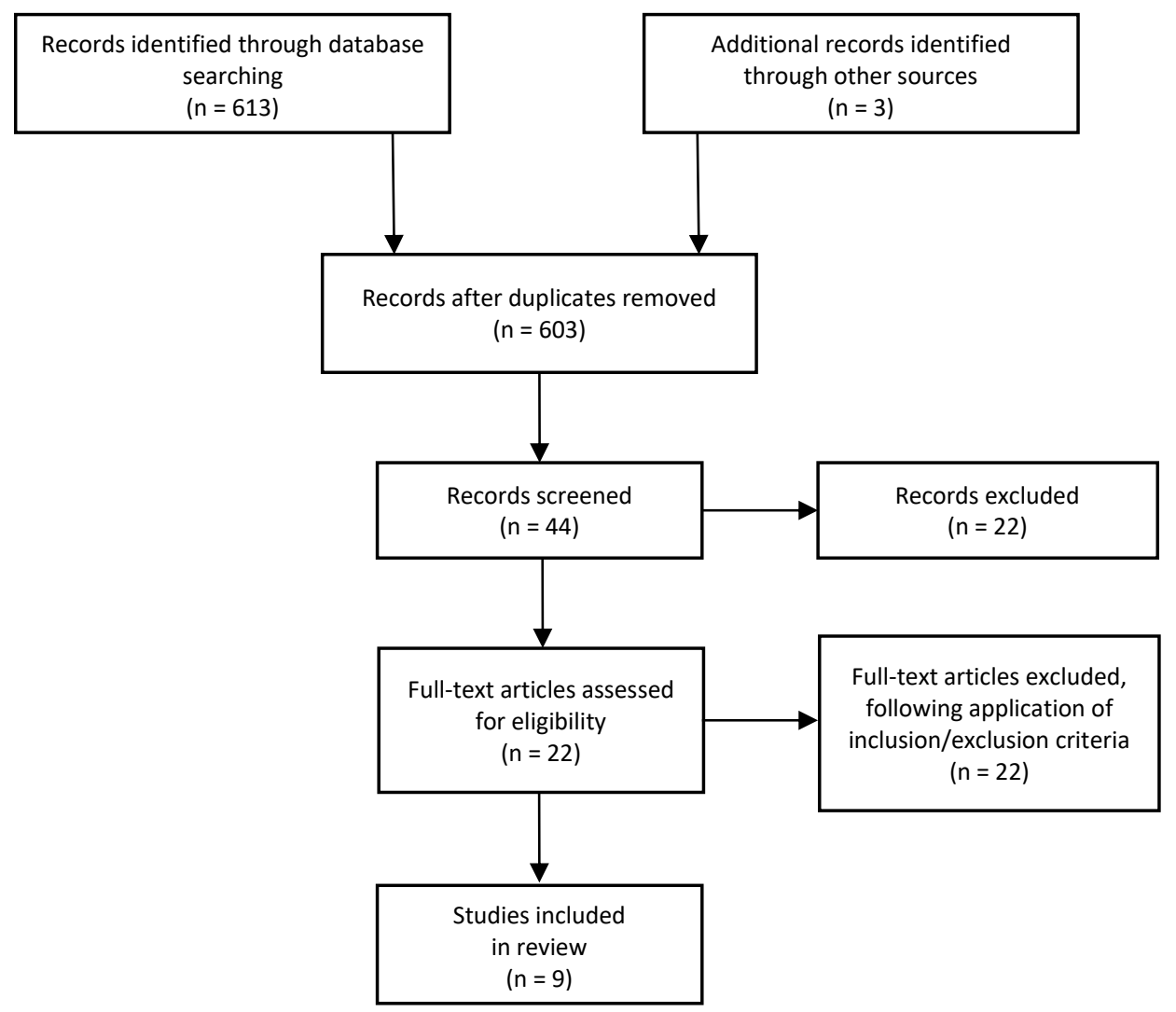

Figure 1: Flow Diagram for the scoping review process 
INTERNATIONAL JOURNAL OF ACADEMIC RESEARCH IN BUSINESS AND SOCIAL SCIENCES

Table 1: Summary of Literature Reviews

\begin{tabular}{|c|c|c|c|c|}
\hline Author, year & Objective or Purpose & Sample & Method & $\begin{array}{l}\text { Findings } \\
\text { (factors relating to psychological well-being) }\end{array}$ \\
\hline $\begin{array}{l}\text { Amit Kumar, } \\
\text { Pookala Shivaram } \\
\text { Bhat, Sumalatha } \\
\text { Ryali; } 2018\end{array}$ & $\begin{array}{l}\text { To study the quality of life } \\
\text { among the health workers } \\
\text { of a large multispecialty } \\
\text { tertiary care hospital and } \\
\text { the factors influencing it }\end{array}$ & $\begin{array}{l}\text { Doctors and } \\
\text { nurses in } \\
\text { large urban } \\
\text { tertiary } \\
\text { care center }\end{array}$ & $\begin{array}{l}\text { An } \\
\text { observation } \\
\text { al study }\end{array}$ & $\begin{array}{l}\text { 1. Occupational stress (predicting factor) } \\
\text { correlated with domains of quality of life of health } \\
\text { care workers } \\
\text { (Role overload, Role insufficiency, Role ambiguity, } \\
\text { Role Boundary, Responsibility, Physical } \\
\text { environment, Psychological strain, Vocational } \\
\text { strain, Physical strain, Interpersonal strain, } \\
\text { Recreation, Self-care, Social support, } \\
\text { Rational/cognitive coping) }\end{array}$ \\
\hline $\begin{array}{l}\text { Manish Gupta, } \\
\text { Musarrat } \\
\text { Shaheen; } 2018\end{array}$ & $\begin{array}{l}\text { To examine the mediating } \\
\text { role of psychological } \\
\text { capital between work } \\
\text { engagement and general } \\
\text { well-being }\end{array}$ & $\begin{array}{l}\text { Health care } \\
\text { employees } \\
\text { of tertiary } \\
\text { hospitals }\end{array}$ & $\begin{array}{l}\text { A criterion } \\
\text { sampling } \\
\text { method }\end{array}$ & $\begin{array}{l}\text { 1. Psychological Capital mediate the relationship } \\
\text { between work engagement and general well-being } \\
\text { (mediating factor) } \\
\text { 2. Work engagement has positive relationship with } \\
\text { general well-being (predicting factor) }\end{array}$ \\
\hline $\begin{array}{l}\text { Mark Durkin, } \\
\text { Elaine Beaumont, } \\
\text { Caroline J. Hollins, } \\
\text { Jerome Carson; } \\
2016\end{array}$ & $\begin{array}{l}\text { To measure associations } \\
\text { between self-compassion, } \\
\text { compassion fatigue, well- } \\
\text { being, and burnout in } \\
\text { nurses }\end{array}$ & $\begin{array}{l}\text { Registered } \\
\text { community } \\
\text { nurses }\end{array}$ & $\begin{array}{l}\text { A cross- } \\
\text { sectional } \\
\text { survey }\end{array}$ & $\begin{array}{l}\text { 1. Compassion satisfaction (predicting factor) } \\
\text { positively associated with compassion for others } \\
\text { and well-being, whilst also being negatively } \\
\text { correlated with burnout }\end{array}$ \\
\hline $\begin{array}{l}\text { Shangping Zhao, } \\
\text { Ling Liu, Hong } \\
\text { Chen; } 2015\end{array}$ & $\begin{array}{l}\text { To determine the factors } \\
\text { influencing the } \\
\text { occupational well-being of } \\
\text { experienced nurses }\end{array}$ & $\begin{array}{l}\text { Experienced } \\
\text { nurses }\end{array}$ & $\begin{array}{l}\text { Semi- } \\
\text { structured } \\
\text { interview }\end{array}$ & 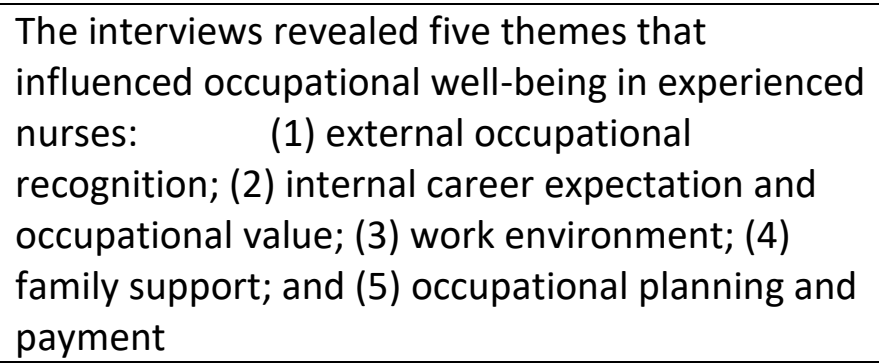 \\
\hline
\end{tabular}


INTERNATIONAL JOURNAL OF ACADEMIC RESEARCH IN BUSINESS AND SOCIAL SCIENCES Vol. 9, No. 2, Feb, 2019, E-ISSN: 2222-6990 @ 2019 HRMARS

\begin{tabular}{|c|c|c|c|c|}
\hline $\begin{array}{l}\text { Fariborz } \\
\text { Rahimnia, } \\
\text { Mohammad } \\
\text { Sadegh Sharifirad; } \\
2014\end{array}$ & $\begin{array}{l}\text { To investigate the } \\
\text { relationship between } \\
\text { authentic leadership, } \\
\text { attachment insecurity and } \\
\text { the three dimensions (job } \\
\text { satisfaction, perceived } \\
\text { work stress, and stress } \\
\text { symptoms) of employee } \\
\text { well-being }\end{array}$ & $\begin{array}{l}\text { Nurses, } \\
\text { medical } \\
\text { professionals } \\
\text { (surgeons } \\
\text { and } \\
\text { physicians) } \\
\text { at hospital in } \\
\text { Iran }\end{array}$ & A survey & $\begin{array}{l}\text { 1. Authentic leadership (predicting factor) has } \\
\text { positive impact on job satisfaction (dimension of } \\
\text { employee well-being) } \\
\text { 2. Attachment insecurity (mediating factor) fully } \\
\text { mediated the relationship between authentic } \\
\text { leadership and perceived stress and stress } \\
\text { symptom (dimension of employee well-being); and } \\
\text { attachment insecurity partially mediated the } \\
\text { relationship between authentic leadership and job } \\
\text { satisfaction }\end{array}$ \\
\hline $\begin{array}{l}\text { Yseult Freeney, } \\
\text { Martin R. Fellenz; } \\
2013\end{array}$ & $\begin{array}{l}\text { To examine the role of } \\
\text { work engagement in } \\
\text { general health of the } \\
\text { midwives delivering care }\end{array}$ & $\begin{array}{l}\text { Midwives } \\
\text { and nurses } \\
\text { at Irish } \\
\text { Maternity } \\
\text { Hospitals }\end{array}$ & $\begin{array}{l}\text { A cross- } \\
\text { sectional } \\
\text { design }\end{array}$ & $\begin{array}{l}\text { 1. Work engagement (mediating factor) partially } \\
\text { mediated between organizational and supervisor } \\
\text { support and general health } \\
\text { 2. Social support (predicting factor) has a direct } \\
\text { link to general health }\end{array}$ \\
\hline $\begin{array}{l}\text { Ronald J. Burke, } \\
\text { Simon L. Dolan, } \\
\text { Lisa Fiksenbaum; } \\
2013\end{array}$ & $\begin{array}{l}\text { To compare the work } \\
\text { experiences, satisfactions, } \\
\text { and psychological well- } \\
\text { being of nursing staff } \\
\text { working full-time vs. part- } \\
\text { time }\end{array}$ & $\begin{array}{l}\text { Nursing staff } \\
\text { working full- } \\
\text { time vs. part- } \\
\text { time }\end{array}$ & $\begin{array}{l}\text { A cross- } \\
\text { sectional } \\
\text { design }\end{array}$ & $\begin{array}{l}\text { 1. Full-time and part-time nursing staff were } \\
\text { similar on marital status, levels of social support } \\
\text { (supervisor, co-worker, spouse, and family), self- } \\
\text { reported absenteeism, levels of burnout, levels of } \\
\text { psychological well-being (psychosomatic } \\
\text { symptoms, self-reported health), and potential } \\
\text { accident propensity }\end{array}$ \\
\hline $\begin{array}{l}\text { Ronald J. Burke, } \\
\text { Eddy S.W. Ng, Lisa } \\
\text { Fiksenbaum; } 2009\end{array}$ & $\begin{array}{l}\text { To examine the } \\
\text { relationship between } \\
\text { virtues and indicators of } \\
\text { work satisfaction and } \\
\text { engagement, perceptions } \\
\text { of hospital functioning and } \\
\text { quality of nursing care, and } \\
\text { psychological well-being of } \\
\text { nursing staff. }\end{array}$ & Staff nurses & $\begin{array}{l}\text { An } \\
\text { exploratory } \\
\text { study }\end{array}$ & $\begin{array}{l}\text { 1. Virtues (predicting factor) accounted for a } \\
\text { significant increment on psychological well-being } \\
\text { (positive affect, psychosomatic symptoms and life } \\
\text { satisfaction) }\end{array}$ \\
\hline
\end{tabular}


INTERNATIONAL JOURNAL OF ACADEMIC RESEARCH IN BUSINESS AND SOCIAL SCIENCES

Vol. 9, No. 2, Feb, 2019, E-ISSN: 2222-6990 @ 2019 HRMARS

\begin{tabular}{|c|c|c|c|c|}
\hline $\begin{array}{l}\text { Jan de Jonge, } \\
\text { Pascale M. Blanc, } \\
\text { Maria C. W. } \\
\text { Peeters, Hanneke } \\
\text { Noordam; } 2008\end{array}$ & $\begin{array}{l}\text { To test the moderating } \\
\text { role of matching and non- } \\
\text { matching job resources in } \\
\text { the relation between } \\
\text { emotional job demands } \\
\text { and employee health and } \\
\text { well-being (emotional } \\
\text { exhaustion, employee } \\
\text { creativity, and work } \\
\text { motivation). }\end{array}$ & $\begin{array}{l}\text { Health care } \\
\text { workers in a } \\
\text { residential } \\
\text { elderly care }\end{array}$ & $\begin{array}{l}\text { A cross- } \\
\text { sectional } \\
\text { survey }\end{array}$ & $\begin{array}{l}\text { 1. Emotional job resources (moderating factor) } \\
\text { moderated the relationship between emotional } \\
\text { demands and emotional exhaustion (well-being) } \\
\text { 2. Cognitive job resources (moderating factor) } \\
\text { moderated the relationship between emotional } \\
\text { job demand and positive well-being outcomes } \\
\text { 3. Emotional job demand (predicting factor) } \\
\text { positively link with well-being outcomes }\end{array}$ \\
\hline
\end{tabular}




\section{Finding and Discussion}

In view of specific keyword of "psychological well-being" and "health care worker" being analyzed, the summary of literature reviews reported that the findings were not only limited to psychological well-being of health care workers. However, quality of life, general health, general wellbeing, employee well-being, occupational well-being and dimension of well-being were also included in the context of this study due to limited resources link to exact keyword of psychological well-being. Considering the specific health care workers categories analyzed, nurses reported as an interesting respondent highlighted on previous literatures. The reason beyond these are due to nurses were considered as the largest workers in the health care sectors and deliver a significant contribution to levels of quality of care and patient satisfaction (Ronald, Simon and Lisa, 2013). In addition, nurses play a crucial role in the delivery quality of health care services. Unfortunately, there is growing evidence that nurses in several countries have become increasingly dissatisfied with their work experience, resulting in lower morale and increased turnover (Ronald, Simon and Lisa, 2013).

According to Shangping, Ling and Hong (2015) reported the interviews revealed five themes that influenced occupational well-being in experienced nurses. Among the factors influencing occupational well-being of experienced nurses include internal career expectation and occupational value; external occupational recognition; family support; family support; work environment; and occupational planning and payment. Meanwhile, as reported, there are no significant differences between full-time and part-time staff nurses on self-reported absenteeism, marital status, level of supervisor, co-worker, spouse and family support, levels of burnout, levels of psychological wellbeing (psychosomatic symptoms, self-reported health), and potential accident propensity (Ronald, Simon and Lisa, 2013).

An analysis of literatures review clearly revealed that there are three main significant factors including predicting, mediating and moderating factors that impacting on psychological well-being of health care workers. The predicting factors provide information on associated dependent variable regarding particular outcomes (Neil, 2010). As referring to the review, several authors reported the predicting factors of psychological well-being including occupational stress (Amit, Pookala and Sumalatha; 2018), work engagement (Manish and Musarrat; 2018), compassion satisfaction (Mark et al., 2016), authentic leadership (Fariborz and Mohammad, 2014), social support (Yseult and Martin, 2013), virtues (Ronald, Eddy and Lisa, 2009) and emotional job demand (Jan et al., 2008). For instance, work engagement has positive relationship with general well-being (Manish and Musarrat; 2018). Hence, it can be concluded that, if health care worker have higher level of work engagement, it consequently result in higher well-being among them.

Meanwhile, mediating factors is referred to a pre-established causal relationship between two variables is theorized to exist due to an intermediate third variable (Baron and Kenny, 1986). According to literatures, several authors revealed that psychological capital (Manish and Musarrat; 2018), attachment insecurity (Fariborz and Mohammad, 2014) and work engagement (Yseult and Martin, 2013). According to Manish and Musarrat (2018), it confirms that work engagement has significant effect on work-related factor such as general well-being, however, the psychological 
capital play a crucial role in facilitating the dimension of work engagement including vigor, dedication and absorption to enhance general well-being.

Furthermore, a moderator is a variable that affects the strength of the relation between the predictor and criterion variable and only Jan et al. (2008) revealed that emotional job resources and cognitive job resources moderated the relationship with the relationship between emotional demands, emotional exhaustion and positive well-being outcomes. Accordingly, job resources could compensate for resources lost through meeting the requirement of emotional job demands, thereby reducing stress-reactions and increasing well-being.

\section{Factor impacting the Psychological Well-Being of Health Care Workers}

Beginning with the factors arising from the literature review, researchers classified several findings into work-related and psychosocial factors impacting on psychological well-being of health care workers in Table 2 . In recent year, there are numerous factors affects work-related well-being and different work-related factors were identified impacting on well-being at work have been evaluated. . As reported, predicting factors relating to work-related well-being among ambulatory workers consist of work engagement, job satisfaction and occupational stress (Melinda et al., 2016). It also supported by Kalashi and Sanet (2013), it revealed four-factorial model relating to work-related well-being in medical laboratory setting consisting the following dimension including occupational stress, job satisfaction, burnout and work engagement.

Meanwhile, an important impact on well-being at work can be attributed to psychosocial factors. Psychological factors on working conditions are considered as risk factors related to many adverse health outcomes including coronary heart diseases (Kivimaki and Kawachi, 2015), musculoskeletal diseases (Kraatz et al., 2013; Hoogendoorn et al., 2000), depression (Theorell et al., 2015) and even suicidal attempts (Woo and Postolache, 2008). However, there is a dearth of knowledge available about the wide range of psychological factors in health care industry. According to WHO well-being index (WHO-5), dimension of psychosocial factors were consist of following categories such as lack of social support, , lack of rewards, job dissatisfaction, job insecurity, excessive work intensity, insufficient job autonomy discrimination and violence. Therefore, the following work and psychosocial related factors impacting psychological well-being of health care worker were divided as follows: 
INTERNATIONAL JOURNAL OF ACADEMIC RESEARCH IN BUSINESS AND SOCIAL SCIENCES Vol. 9, No. 2, Feb, 2019, E-ISSN: 2222-6990 ㄷ 2019 HRMARS

Table 2: Factors impacting psychological well-being of health care workers

\begin{tabular}{|l|l|}
\hline \multicolumn{1}{|c|}{ Work-related Factor } & \multicolumn{1}{|c|}{ Psychosocial-related factor } \\
\hline 1. Occupational stress & 1. Psychological capital \\
2. External occupational recognition & 2. Occupational planning and \\
3. Internal career expectation and & payment \\
occupational value & 3. Compassion satisfaction \\
4. Work engagement & 4. Work environment \\
5. Emotional job demands & 5. Family support \\
& 6. Authentic leadership \\
& 7. Attachment insecurity \\
& 8. Virtues \\
& 9. Organizational support \\
& 10. Supervisor support \\
& 11. Emotional job resources \\
& 12. Cognitive job resources \\
\hline
\end{tabular}

\section{Limitation}

The scoping review offers several limitations that need to be addressed. It aims to explore what is known about health care workers and factor impacting on their psychological well-being. In addition, the review required extensive literatures reading and some of relevant literatures may have been omitted, due to selection of literatures were only selected using English language. Furthermore, all literatures included in this study involved health care workers mainly in Western countries. Besides, literatures obtained only covered health care workers including nurses, physicians, doctors, surgeons and medical laboratory workers within public and private health care providers. Thus, more in-depth study in psychological well-being of health care workers relating to work-related and psychosocial factors is need for future research.

\section{Conclusion}

Through the analysis of previous literatures presented, this paper contributes to general theme of well-being and more specifically to health care sector by providing an updated literature reviews relating to factors impacting on psychological well-being of health care workers. In particular, the analysis of literatures revealed several factors relating to health care workers' well-being including occupational stress, work engagement, authentic leadership, social support and others. Hence, by reviewing findings associated with well-being, this study proposed integrated view of work and psychosocial related factors impacting on psychological well-being by assisting health care providers in better searching for overall solution in dealing with workers malaise. It must be recognized that the present findings were influenced by the significant number of literatures focusing on nurses and thus might not be easily generalized to all health care workers. Thus, more in-depth study in psychological well-being of health care workers relating to work-related and psychosocial factors across occupation and different setting of health care sectors is needed for future research. 
INTERNATIONAL JOURNAL OF ACADEMIC RESEARCH IN BUSINESS AND SOCIAL SCIENCES

Vol. 9, No. 2, Feb, 2019, E-ISSN: 2222-6990 ㄷ 2019 HRMARS

\section{References}

Angela, B. \& Kenneth, G. (2013). An evaluation of health and well-being checks for unpaid carers. Journal of Integrated Care, Vol. 21 (3), pp. 148-156.

Bennett, P., Williams, Y., Page, N. (2004). Levels of mental health problems among UK emergency ambulance workers. Emergency Medicine Journal: EMJ, Vol. 21, pp. 235-236.

Demo, G. \& Paschoal, T. (2013). Well-being at work scale: Explatory and confirmatory validation in the United States comprising affective and cognitive components. Anais do Encontro Nacionalda Associacao Nacional de Pos-Graduacao e Pesquisaem Adminstracao, Rio de Janeiro, Brazil, p. 27.

De Simone, S. (2015). Expectancy value theory: Motivating healthcare workers. American International Journal of Contemporary Research, Vol. 5 (2), pp. 19-23.

Fariborz, R., \& Mohammad, S.S. (2015). Authentic leadership and employee well-being: The mediating role of attachment insecurity. Journal of Business Ethics, pp. 365-377.

Headey, B., Kelley, J., \& Wearing, A. (1993). Dimensions of mental health: Life satisfaction, positive anxiety and depression. Social Indicator Research, Vol. 29, pp. 63-82.

Hoogendoorn, W.E., Van Poppel, M.N., Bongers, P.M., Koes, B.W., \& Bouter, L.M. (2000) Systematic review of psychosocial factors at work and private life as risk factors for back pain. Spine, Vol. $25,2114-2125$.

Jan, D.J., Pascale, M.L.B., Maria, C.W.P. \& Hanneke, N. (2008). Emotional job demands and the role of matching job resources: A cross sectional survey study among health care workers. International Journal of Nursing Studies, Vol. 45, pp. 1460-1469.

Kivimäki, M., \& Kawachi, I. (2015). Work Stress as a Risk Factor for Cardiovascular Disease. Current Cardiology, Vol. 17, p. 630.

Kraatz, S., Lang, J., Kraus, T., Münster, E., Ochsmann, E. (2013). The incremental effect of psychosocial workplace factors on the development of neck and shoulder disorders: a systematic review of longitudinal studies. International Occupational Environmental Health, Vol. 86, pp. 375-395.

Kuo, H.T., Lin, K.C., Li, I.C. (2014). The mediating effects of job satisfaction on turnover intention for long-term care nurses in Taiwan. Journal of Nursing Management, Vol. 22, pp. 225-233.

Li, J., Fu, H., Hu, Y., Shang, L., Wu, Y., \& Kristensen, T.S. (2010), Psychosocial work environment and intention to leave the nursing profession: results from the longitudinal Chinese NEXT study. Journal of Public Health, Vol. 38, pp. 69-80.

Maben, J., Peccei, R., Adams, M., Robert, G., Richardson, A., \& Murrells, T. (2012). Exploring the relationship between patients' experiences of care and the influence of staff motivation, affect and wellbeing. Southampton: NIHR Service Delivery and Organisation Programme.

Mackenzie C.S., Poulin P.A., \& Seidman-Carlson R. (2006). A brief mindfulness-based stress reduction intervention for nurses and nurse aides. Application Nurse Resources, Vol.9, pp. 105.

Manish Gupta, \& Musarrat Shaheen, (2018). Does work engagement enhance general well-being and control at work? Mediating role of psychological capital. Evidence-based HRM: a Global Forum for Empirical Scholarship, Vol. 6 (3), pp. 272-286.

Mark D., Elaine B. (2016). A pilot study exploring the relationship between self-compassion, selfjudgement, self-kindness, compassion, professional quality of life and wellbeing among UK community nurses. Nurse Education Today, Vol. 46, pp. 109-114. 
Pawar, B.S. (2016). Workplace spirituality and employee well-being: An empirical examination. Employee Relations, Vol. 38 (6), pp. 975-994.

Payne, R. L., \& Firth-Cozens, J. (1987). Stress in Health Professionals. Hoboken, NJ: John Wiley \& Sons.

Peters, M.D.J., Godfrey, C., M, McInerney, P., Soares, C.B., Khalil, H., \& Parker, D., (2015). The Joanna Briggs Institute Reviewers' Manual 2015: Methodology for JBI Scoping Reviews. The Joanna Briggs Institute., Adelaide.

Ramirez, A.J., Graham, J., \& Richards, M.A., et al. (1996). Mental health of hospital consultants: The effects of stress and satisfaction at work. The Lancet. Vol. 347(9003), pp. 724-728.

Rees, D., \& Cooper, C. L. (1992). Occupational stress in health service workers in the UK. Stress Medicine, Vol. 8(2), pp. 79-90.

Rodwell, J., Munro, L. (2013). Well-being, satisfaction and commitment: the substitutable nature of resources for maternity hospital nurses. Journal of Advance Nursing, Vol. 69, pp. 2218-2228.

Shangping, Z., Ling, L. \& Hong, C. (2015). Factors influencing the occupational well-being of experienced nurses. International Journal of Nursing Sciences, Vol. 2, pp. 378-382.

Synder, C. R., Lopez, S.J., Pedrotti, J.T. (2011). Positive psychology: The scientific and practical explorations of human strengths. (2 ${ }^{\text {nd }}$ Ed.). Sage Publications.

Ronald, J., Burke, E. S. W. Ng, L. F. (2009). Virtues, work satisfactions and psychological wellbeing among nurses. International Journal of Workplace Health Management, Vol. 2(3), pp. 202219.

Ronald, J. B., Simon, L. D., Lisa, F. (2013). Part-time versus full-time work: An empirical evidencebased case of nurses in Spain. Evidence-based HRM: A global forum for empirical scholarship, Vol. 2 (2).

Theorell, T., Hammarström, A., Aronsson, G., Träskman, B. L., Grape, T., Hogstedt, C., Marteinsdottir, I., Skoog, I., \& Hall, C. (2015). A systematic review including meta-analysis of work environment and depressive symptoms. BMC Public Health, Vol. 15, p. 738.

Woo, J. M., \& Postolache, T. T. (2008) The impact of work environment on mood disorders and suicide: Evidence and implications. International Journal of Disability Human Development, Vol. 7, pp. 185-200.

Wright, T. A., \& Bonett, D. G. (2007). Job satisfaction and psychological well-being as non-addictive predictors of workplace turnover. Journal of Management, Vol. 33, pp. 141-160.

Yseult, F. \& Martin, R. F. (2013). Work engagement as a key driver of quality of care: A study of with midwives. Journal of Health Organization and Management, Vol. 27(3), pp. 33.-349. 